$\mathbf{R}_{\text {ESEARCH }} \mathbf{P}_{\text {APER }} \longrightarrow$ FOOD SCIENCE Volume 8 | Issue 2 | October, 2017 | 230-234 DOI : $10.15740 / \mathrm{HAS} / \mathrm{FSRJ} / 8.2 / 230-234$

\title{
Nutritional analysis and organoleptic evaluation of paddy straw mushroom (Volvariella sp.)
}

\author{
G.B. Brinda, Susha S. Thara and Suma Divakar
}

\begin{abstract}
Mushroom is regarded as one of the highly priced delight of vegetarians. Mushroom is the only non animal source of vitamin $\mathrm{D}$ with various nutritional advantages. It has found a prominent place in the kitchens of majority of people in the world. Nowadays mushrooms are gaining paramount importance as a low calorific food with good quality protein and high fibre content. Edible mushrooms are additionally exploited for their medicinal properties in the present age as it has already proven as promising with hepato-protective, anticancer, antioxidant, antiviral, hypoglycaemic and hypercholesterolemia effects. In this context, nutritional analysis of paddy straw mushroom was performed and the content of various proximate constituents like carbohydrates, protein, lipids, fibre and ash were evaluated and sensory evaluation was carried out in comparison with button mushroom, oyster mushroom and milky mushroom using two recipes. Paddy straw mushroom recipe was liked very much by most of the evaluators. Paddy straw mushroom was found to possess better quality with respect to nutritional value and organoleptic acceptability.
\end{abstract}

Key Words : Paddy straw mushroom, Nutritional analysis, Organoleptic evaluation

How to cite this article : Brinda, G.B., Thara, Susha S. and Divakar, Suma (2017). Nutritional analysis and organoleptic evaluation of paddy straw mushroom (Volvariella sp.). Food Sci. Res. J., 8(2): 230-234, DOI : 10.15740/HAS/FSRJ/8.2/230-234.

Author for correspondence :

G.B. BRINDA, Department of Plant Pathology, College of Agriculture, Vellayani, THIRUVANANTHAPURAM (KERALA) INDIA

Email : brinda.brindavan@gmail.com

Associate Authors' :

SUSHA S. THARA, Department of Plant Pathology, College of Agriculture, Vellayani, THIRUVANANTHAPURAM (KERALA) INDIA

Email : susha.thara@kau.in

SUMA DIVAKAR, Department of Community Science, College of Agriculture, Vellayani, THIRUVANANTHAPURAM (KERALA) INDIA

Email : divakarsuma67@gmail.com 